\title{
SHAPING OF THE WIDTH OF TREE RINGS IN SCOTS PINE AS A RESULT OF RESIN TAPPING
}

\author{
Krzysztof Michalec*, Radosław Wąsik, Anna Barszcz
}

Department of Forest Utilisation, Forest Engineering and Technology, Faculty of Forestry, University of Agriculture in Krakow, al. 29 Listopada 46, 31-425 Krakow

\section{ABSTRACT}

The study material was taken from a stand in the Świerklaniec Forest Division from a 164-year-old pine stand. Resin was tapped from the stand in question in 1964-1965 in a 2 -year cycle. In the case of pines with single resin tapping areas, the notches were made on trees' west side. From felled trees, 3 pieces with tapping areas were selected. Then, 3 wood discs were retrieved from the felled trees at the following heights: discs marked with A - $1 \mathrm{~m}$ from the intersection of the thicker end, within the tapping area made 47 years earlier (in the 2nd year of tapping) and B - at a distance of $2.60 \mathrm{~m}$ and C at a distance of $3.80 \mathrm{~m}$ from the intersection. Rings $\mathrm{B}$ and $\mathrm{C}$ were above the top edge of the notch. Samples for comparison were taken with an increment borer from 3 standing, non-tapped trees on the height of $1.30 \mathrm{~m}$ from the base of the trees, from the west and east. The collected material was analysed by measuring the width of the radial growth of the trunk of tapped and non-tapped trees from the west and east, taking into account two zones: 1 - internal, from the core to 1965, i.e. to the second year of tapping, and 2 external, from 1966 to 2012.

For all trees, tapped and non-tapped, the average widths of annual growth in internal zones were larger than in external zones. For tapped trees at the height A, eastwards, i.e. on the side that is vital for the tree nutrition system, or the vital strip, the average widths of growth were only $12.3 \%$ smaller in the outer zone than in the inner zone. Corresponding difference in non-tapped trees was as much as $60.4 \%$. In tapped trees on the extension of the tapping areas (on the west side), at the heights B and C, the average widths of rings in

\footnotetext{
* $\bowtie$ krzysztof.michalec@urk.edu.pl
} 
the outer zone were respectively $53.1 \%$ and $50.0 \%$ smaller than in the inner zone. On the east side, on the extension of the vital strip, at height B, they were smaller only by $37.3 \%$, and at the height C by $39.2 \%$ than in the internal zone. This study confirmed the theory of optimising the shape of the tree by increasing the growth in the perimeter part that was not directly affected by mechanical damage; in this case, the damage was caused by resin tapping notches.

\section{KEYWORDS}

resin tapping notches $\bullet$ wood defects $\bullet$ trunk deformation $\bullet$ mechanical damage

\section{Introduction and purpose of research}

In the period from the end of World War II until 1993, an average of 16,000 tonnes of pine resin annually were obtained in Poland. The largest extraction, reaching over 20 thousand tonnes/year took place from the beginning of the 1960s to the mid-1970s (Grochowski 1990). At that time, the income from the sale of resin was important for some forest divisions, second after the sale of raw wood. From the mid-1970s, there was a sharp regression in resin extraction. Resin tapping ended in 1994, which was mainly determined due to economic reasons. Domestic balsamic resin was replaced by cheaper, though inferior, imported raw material. Another factors that affected this situation were the long-term weakening of pine stands by industrial immissions, black arch gradation and negative opinions of environmentalists critical of the resin tapping process that is related to the intentional wounding of live trees. Currently, Poland no longer imports resin, but readymade resin products are imported - rosin, turpentine and flotation oil, which are in great demand in many areas of our economy (Barszcz 2007).

In accordance with the requirements of the instructions (Instruction... 1987), the resin tapping process was planned in such time that the tree felling would take place in the next winter season, after the collection of resin. Compliance with a series of detailed recommendations included in the instructions enabled the preservation of the tapped trees at the level of health and vitality they had before the treatment, and prevented the negative consequences in the form of lowering the quality of raw wood up to the moment of felling. Despite the passing of more than 25 years since the last year of resin tapping, there are still pine trees with resin tapping notches, often made before 1993. In Poland, but also in neighbouring countries, research has been undertaken for many years on the quality and value of wood of tapped pines (Frommhold and Temmen 1995, Kätzel et al. 1995, Magnuszewski and Tomusiak 2013). Mechanical damage caused during resin extraction is likely to affect tree growth. Few studies have analysed the effect of resin extraction on tree growth but these studies often produce conflicting results. Research carried out in Poland and Germany shows that resin extraction has a positive effect on the radial growth of Scots pine at the height of diameter at breast height, or DBH, but does not affect the growth above the tapping area (Tomusiak and Magnuszewski 2009, van der Maaten et al. 2017). In turn, research in Greece, Spain 
and China indicates that the extraction of resin negatively affects the growth of pine (Papadopoulos 2013, Génova et al. 2014, Chen et al. 2015). These differences may (partly) refer to the differences in the autecology of the pine species studied, as well as to the differences in the resin extraction methods used (Chen et al. 2015).

The purpose of this study was to determine the impact of resin tapping performed in 1965-1966 on the width of annual growth of Scots pine left on the trunk until 2012, in relation to non-tapped trees.

\section{Material and methods}

The study material in the form of discs cut from tree trunks was taken from the stand in the Świerklaniec Forest Division (Katowice Regional Directorate of the State Forests), Mikołeska Forest District (section 150d) $\left(50^{\circ} 45^{\prime} \mathrm{N}, 18^{\circ} 91^{\prime} \mathrm{E}\right)$. It was a 164 -year-old pine stand, growing in a habitat of fresh mixed coniferous forest, classified as III class according to the site index. The stand in question was being tapped in 1964-1965 in a 2 -year cycle, using notches on the height of $2 \mathrm{~m}$. On pines with single tapping areas, from which the material was collected, notches were made from the west (Photo 1).
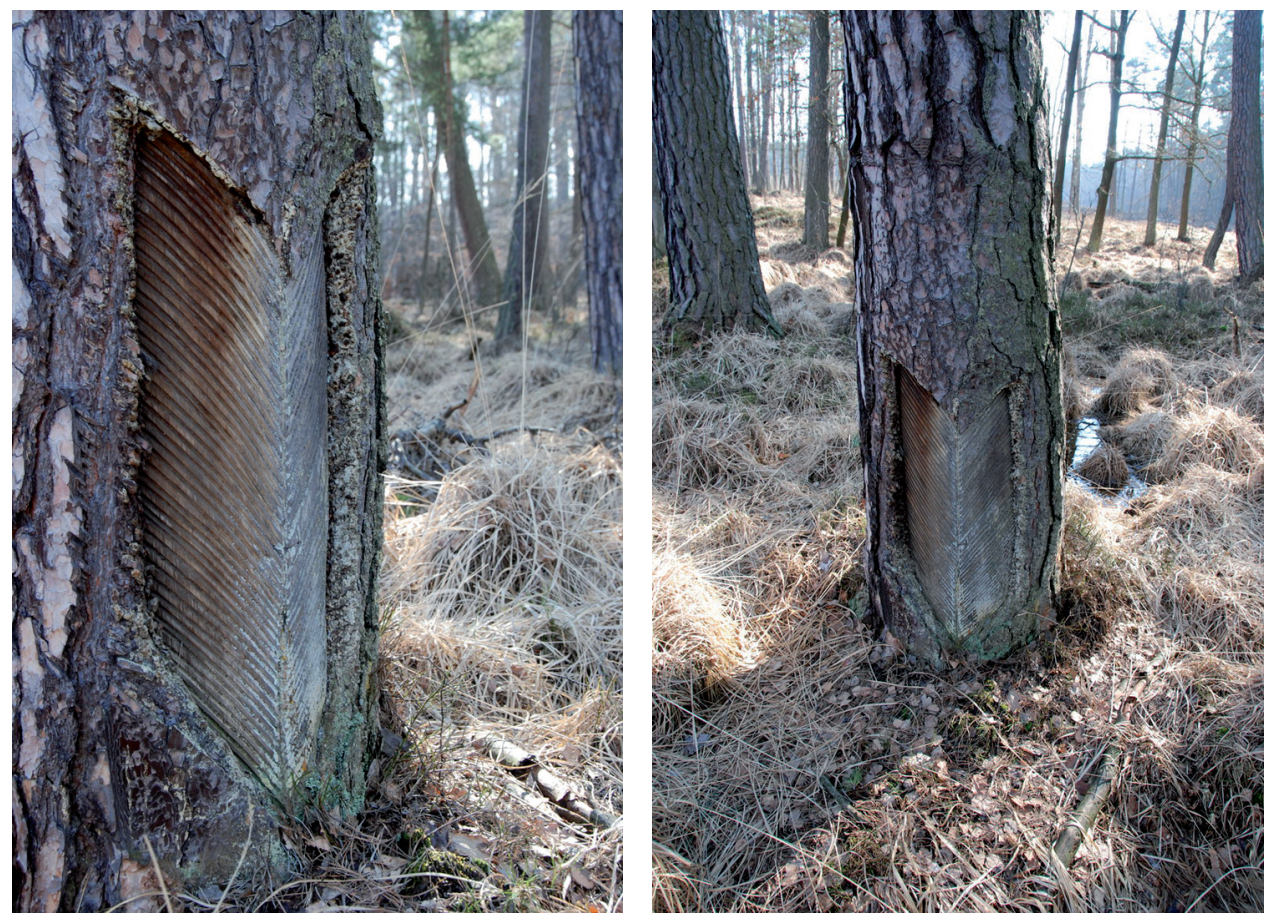

Photo 1. The view of tapping areas in the stand from which samples were taken (photo A. Barszcz) 
Single tapped pines remained in this condition until the 2012 tree felling in the stand. From felled trees, 3 pieces with tapping areas were selected. Due to a significant deformation of tree butts, current tree DBHs were not measured, but it was found that at the time of making the notches, the average DBH was $24.7 \mathrm{~cm}$ without bark (about $27 \mathrm{~cm}$ with bark). The DBH was determined by measuring the diameter of the trunk zone seen on the cross-section (disc) until making the notches. Then, 3 wood discs were retrieved from the felled trees at the following heights: discs marked with A - $1 \mathrm{~m}$ from the intersection of the thicker end, within the notches made 47 years earlier (in the 2nd year of tapping) and $\mathrm{B}-$ at a distance of $2.60 \mathrm{~m}$ and $\mathrm{C}$ at a distance of $3,80 \mathrm{~m}$ from the intersection. Rings $\mathrm{B}$ and $\mathrm{C}$ were above the top edge of the tapping area. The discs from level A $(1 \mathrm{~m})$ corresponded to the height of the standing trees $\mathrm{DBH}$, because about $30 \mathrm{~cm}$ of the height of the stump obtained after cutting down the tapped trees was added.

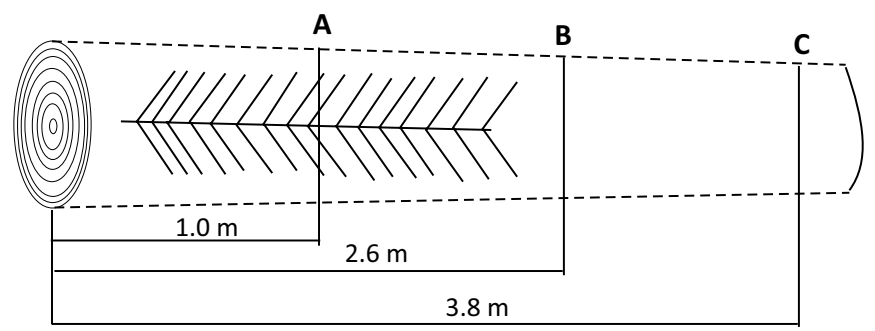

Fig. 1. Material collection scheme

Samples for comparison were taken with an increment borer from 3 standing, nontapped trees on the height of $1.30 \mathrm{~m}$ from the base of the trees, from the west and east (samples marked with the $\mathrm{N}$ symbol). Similarly as for tapped trees, it was determined that the average DBH of these pines was about $20.3 \mathrm{~cm}$ without bark (22 cm with bark) in 1964. This diameter was determined based on the length of the radius on the borehole with the appropriate number of annual increments since planting the tree until 1964. These findings showed that the non-tapped trees were about $5 \mathrm{~cm}$ thinner compared to the tapped trees. This difference resulted from the recommendations included in the Instruction (1987) that in III site index class stands, viable and well growing trees with the $\mathrm{DBH}$ of not less than $20 \mathrm{~cm}$ shall be used for tapping.

The collected material was analysed by measuring the width of the radial increments of the trunks of tapped and non-tapped trees from the $\mathrm{W}$ - west (tapping area side) and $\mathrm{E}$ - east (opposite side). Before measurements, a cross-section of annual rings was made and then scanned. The annual rings width was measured using the "Przyrost WP" programme (Biotronik 2001). In the further stage of analysis, the division of increments into 2 zones was used: 1 - internal, from the core to 1965 , i.e. until the second year of tapping, and 2 - external, from 1966 to 2012 (Fig. 2).

Statistical characteristics of the average width of rings of the examined trees were made, in accordance with the distinguished heights on the trunk and cross-sectional 
areas. Then, using the Shapiro-Wilk test $(\mathrm{p}<0.05)$, the compliance of the empirical data distribution with the normal distribution was checked. Due to the lack of normality of the distribution of variables, in the next stage of the research, it was analysed, using the Kruskal-Wallis test and the multiple-comparison (post-hoc) test $(\mathrm{p}<0.05)$, whether the average widths of annual rings in the distinguished trunk cross-section radius differ significantly from each other. Statistical analyses were performed with the Statistica 12 software.
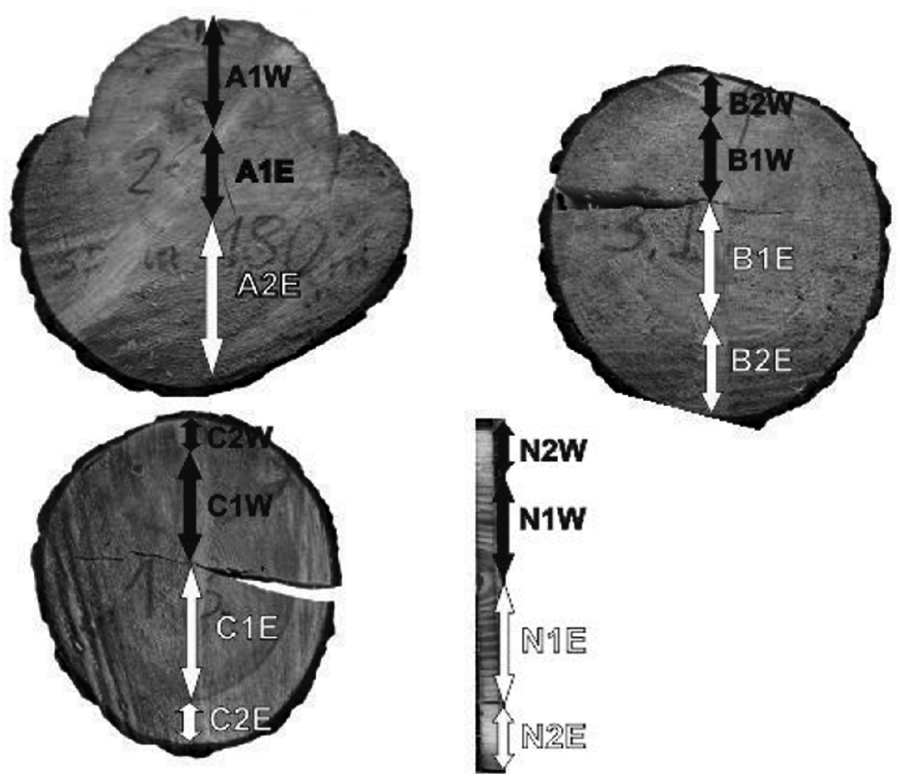

Explanations: symbols are given in the Methodology

Fig. 2. Scheme for collecting material from tapped and non-tapped trees

\section{Research results}

The widths of the radial growth of pines with tapping areas analysed within zones 1 and 2, i.e. before and after resin tapping, were: at the height of the $\mathrm{DBH}(\mathrm{A})$ in the range from 0.95 to $1.30 \mathrm{~mm}$, higher at the level $\mathrm{B}$ in the range from 0.46 to $1.26 \mathrm{~mm}$, and at the highest level $\mathrm{C}$ from 0.48 to $1.25 \mathrm{~mm}$. In non-tapped trees at the $\mathrm{DBH}$ height, the average width of the rings in zones 1 and 2 (internal - near the core, and external - near the circumference, respectively), ranged from $0.39-1.11 \mathrm{~mm}$. A large variation, in the range of 95.1-101.08\%, was observed in annual growth rings of non-tapped trees in zone 1. Coefficients of variation in growth of non-tapped trees in zone 2 as well as in both zones ( 1 and 2 ) of tapped trees, at different heights were smaller and appeared at lower levels, from 53.17 to $79.22 \%$ (Table 1). 
Table 1. Basic statistical characteristics of the average width of annual increments of resin tapped and non-tapped pines

\begin{tabular}{|c|c|c|c|}
\hline Zone & Average & Standard deviation & Variability coefficient \\
\hline $\mathrm{A} 1 \mathrm{~W}$ & 0,95 & 0,51 & 53,17 \\
\hline $\mathrm{A} 1 \mathrm{E}$ & 1,30 & 0,85 & 65,54 \\
\hline $\mathrm{A} 2 \mathrm{E}$ & 1,14 & 0,89 & 78,59 \\
\hline N1W & 0,71 & 0,72 & 101,08 \\
\hline $\mathrm{N} 2 \mathrm{~W}$ & 0,39 & 0,23 & 60,44 \\
\hline $\mathrm{N} 1 \mathrm{E}$ & 1,11 & 1,05 & 95,10 \\
\hline $\mathrm{N} 2 \mathrm{E}$ & 0,44 & 0,27 & 60,80 \\
\hline $\mathrm{B} 1 \mathrm{~W}$ & 0,98 & 0,74 & 75,10 \\
\hline $\mathrm{B} 2 \mathrm{~W}$ & 0,46 & 0,35 & 77,33 \\
\hline $\mathrm{B} 1 \mathrm{E}$ & 1,26 & 0,79 & 62,87 \\
\hline $\mathrm{B} 2 \mathrm{E}$ & 0,79 & 0,60 & 75,20 \\
\hline $\mathrm{C} 1 \mathrm{~W}$ & 0,96 & 0,68 & 70,46 \\
\hline $\mathrm{C} 2 \mathrm{~W}$ & 0,48 & 0,38 & 79,22 \\
\hline $\mathrm{C} 1 \mathrm{E}$ & 1,25 & 0,87 & 69,39 \\
\hline $\mathrm{C} 2 \mathrm{E}$ & 0,76 & 0,59 & 77,23 \\
\hline $\mathrm{AE}$ & 1,24 & 0,87 & 69,85 \\
\hline BW & 0,83 & 0,69 & 83,12 \\
\hline $\mathrm{BE}$ & 1,12 & 0,77 & 68,54 \\
\hline CW & 0,83 & 0,65 & 77,78 \\
\hline $\mathrm{CE}$ & 1,12 & 0,83 & 74,39 \\
\hline NW & 0,56 & 0,40 & 71,30 \\
\hline $\mathrm{NE}$ & 0,82 & 0,74 & 90,24 \\
\hline
\end{tabular}

Explanations: symbols are given in the Methodology chapter

The analysis of the average width of increments in the cross-sectional zones suggests that all the pine trees tested were characterised by eccentricity of the core. The width of the rings, and therefore also the cross-sectional radius of the trunks was greater eastwards than westwards. This was probably due to the prevailing winds in the studied area - from the west. It was also found that in tapped trees at the 3 examined height levels, as well as in non-tapped trees at the $\mathrm{DBH}$ height, the average width of the zone 
2 (outer) rings was significantly smaller compared to the zone 1 (inner) rings. These differences were statistically significant (Kruskal-Wallis test: $\mathrm{H}=332.21 ; \mathrm{p}=0.0000$ ).

Due to the purpose of the study, it was important to determine the changes (resulting from tapping) in the annual rings width in tapped trees compared to non-tapped trees. It was determined that for tapped trees at the height A, eastwards, i.e. on the vital strip, the average widths of growth were only $12.3 \%$ smaller in the outer zone than in the inner zone (Fig. 3).

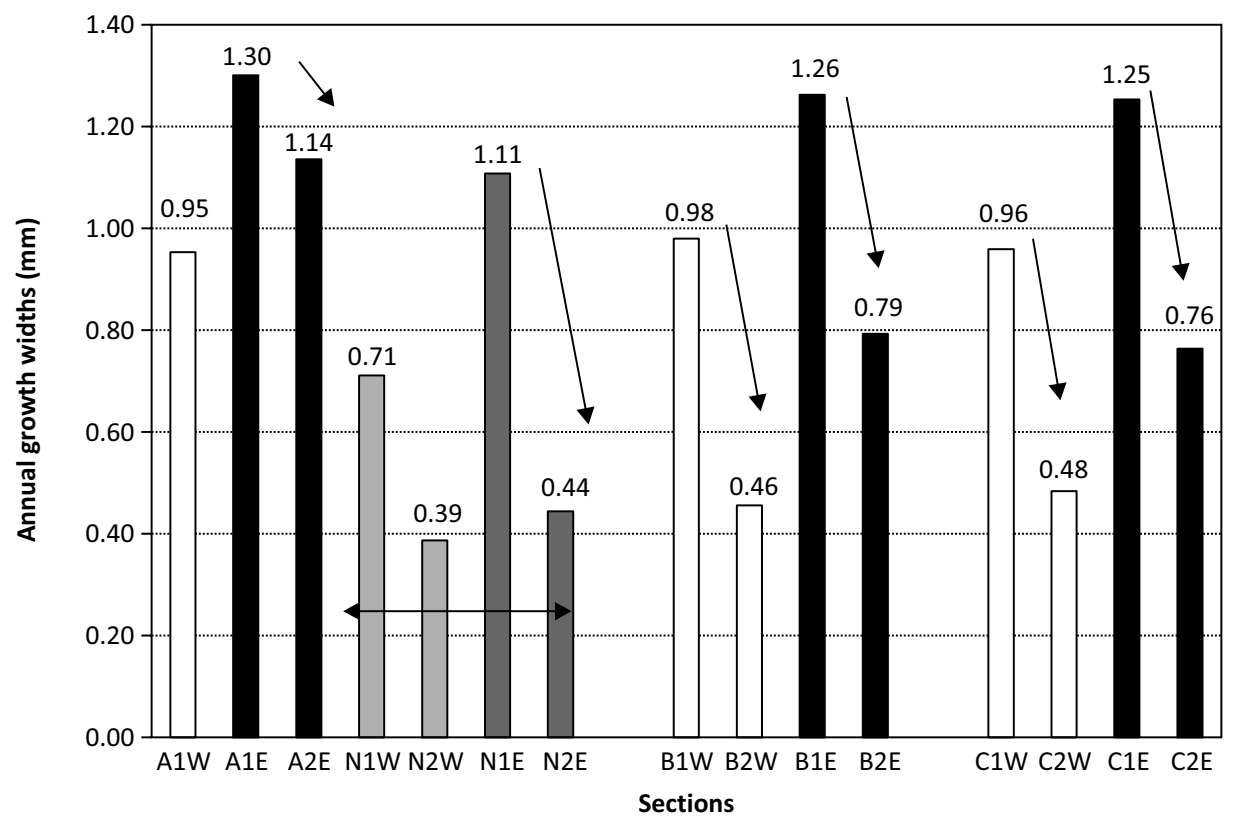

Explanations: symbols as in Figure 2

Fig. 3. Average widths of radial increments of tapped and non-tapped pines

Corresponding difference in non-tapped trees was as much as $60.4 \%$. In addition, in the tapped trees, the average width of the rings at the level $\mathrm{A}$ in the peripheral zone from the east was $159 \%$ larger than in the same zone in non-tapped trees. In the tapped trees, on the extension of the tapping area (on the west side), at the heights B and C, the average widths of rings in the outer zone were $53.1 \%$ and $50.0 \%$ smaller, respectively, than in the inner zone. On the east side, on the extension of the vital strips, at the height $\mathrm{B}$, they were smaller only by $37.3 \%$, and at the height $\mathrm{C}$ by $39.2 \%$ than in the internal zone. Therefore, the tapping area was clearly influencing the width of the rings after tapping at the level $\mathrm{A}$, and the influence was also visible (though weaker) above the vital strip at the B and C heights. The Kruskal-Wallis test and the post hoc test of multiple comparisons showed that all of the above differences were statistically significant $(\mathrm{H}=$ 714.21; $\mathrm{p}=0.0000)$. 
The dynamics of changes in the width of radial increments of tapped and nontapped trees is shown in Figure 4. Regardless of the trunk level from which the material was obtained, the curves always relate to the same period - from 1960 to 2012. In the course of the curves, it can be seen that in the first 60 years there are clear differences between the width of rings of non-tapped trees and the trees later subjected to resin tapping which grew more intensively and, therefore, were selected for tapping. Then, within about 20 years, the curves do not differ much from each other. In the mid-1960s, after tapping, the width of the rings began to increase intensively, especially at the height of tapping area, on the side of the vital strip (AE curve). A relatively large increase in radial increment can also be seen at the heights $\mathrm{B}$ and $\mathrm{C}$ (BE and $\mathrm{CE}$ curves), above the vital strip. The smallest dynamics of the growth widths, similar to the course of the curves of non-tapped trees, can be seen at the heights B and C on the west side, i.e. above the tapping areas. This indicates a disturbance in the regularity of the cross-sectional shape of the trunks after resin tapping, which intensifies over time and mainly affects the butt part.

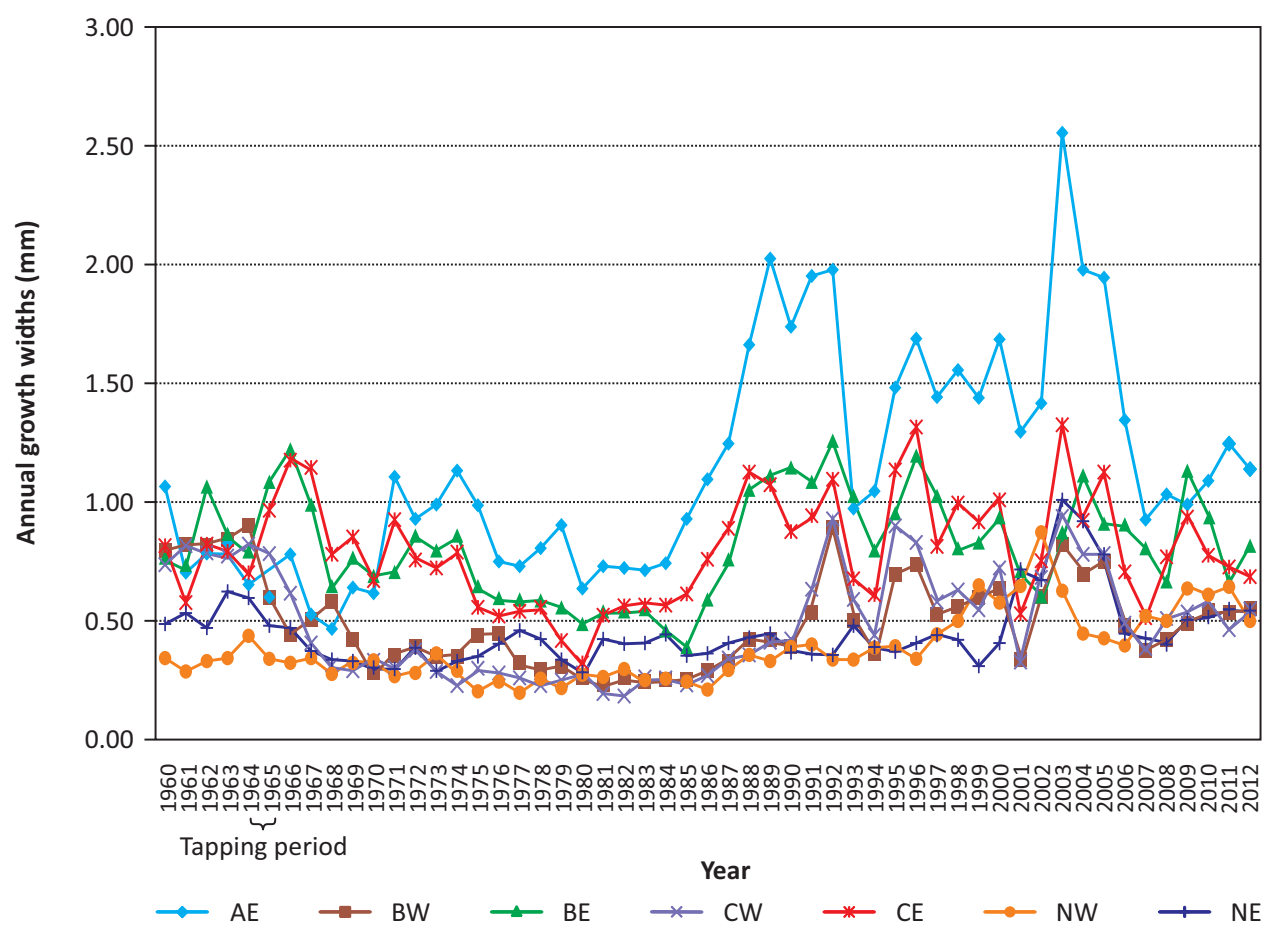

Explanations: symbols as in Figure 2

Fig. 4. Dynamics of changes in the average width of annual increments of resin-tapped and non-tapped pines on the cross-section radius of trunks 


\section{Discussion}

Wounding trees during resin tapping causes disturbance in their life processes. The creators of resin tapping principles were aware of this, as they preceded developing of the instructions with multidirectional long-term studies of the consequences of the procedure. They tried to optimise the rules and methods of resin tapping in such a way that the impact on physiological processes, tree health, as well as wood growth and quality was as small as possible, while trying to achieve the highest possible efficiency (Instructions... 1987, Grochowski 1990). This influence and the reaction of living trees to the disturbance of conducting functions and changes in moisture content of wood tissue caused by resin tapping notches is associated with the classic Jaccard theory (Jelonek 2013), in which the leading impact of trunk hydraulics on dimensional parameters and shape of tree trunks was emphasised. On the basis of tomographic examinations it was also found that the drastic decrease in wood humidity in zones adjacent to the resin tapping areas is compensated by an increase in humidity of other living parts of sapwood (Kätzel et al. 1995).

In turn, the mechanical theory of Metzger (Jelonek 2013) is based on the assumption that the shape of tree trunks is modified by the stresses occurring in them. This refers to the situation when due to the damaging and reducing the cross-sectional area of the trunk in the peripheral part, among others as a result of making resin tapping notches, the increments on the undamaged part of the trunk (in this case on the vital strip) are increased so that the stresses occurring there would spread over a larger area.

As early as in 1930, Jezierski (1930), and later Grochowski (1990), citing numerous Soviet authors, state that as a result of long-term, intensive resin tapping, the annual growth of wood on and above vital strips increases significantly. In addition, if a tree is not subjected to felling for a long time after resin tapping, a significant deformation of the butt occurs. As a result of the authors' research, it was also found that pine trees that were not felled for several dozen years after resin tapping grew more intensively on the vital strips than non-tapped pines at the same trunk level. It was found that also above the vital strips, at $2.60 \mathrm{~m}$ and $3.80 \mathrm{~m}$ levels, growths were still larger than on the opposite sides, i.e. on the extension of resin tapping area.

The research by Magnuszewski and Tomusiak (2013) shows that in the 40-year period after resin tapping, the radial growths of the studied pines at the $1.30 \mathrm{~m}$ level on the vital strips, increased significantly compared to non-tapped pines. This result confirms the relationship described by Grochowski (1990) and van der Maaten et al. (2017), and observed as a result of the research. The cited authors did not find, however, any impact of resin tapping on the width of the rings on the extension of the vital strips, $30 \mathrm{~cm}$ above the upper border of tapping areas. Such impact is reported by Grochowski (1990) and has been confirmed as a result of this research. In turn, research by other authors (Papadopoulos 2013, Génova et al. 2014, Chen et al. 2015) report a decrease in annual growth in resin tapped pines from $14.1 \%$ to $33 \%$ compared to non-tapped pines. These differences may result from the resin tapping of other pine species (Poland, Germany - Pinus silvestris, Greece - Pinus halepensis, Spain - Pinus pinaster, China - Pinus masso- 
niana) and different tapping methods (by making notches, by removing patches of bark). There are also studies conducted on Pinus massoniana in China (Williams et al. 2017), which in turn do not show any impact on annual growth in tapped pines.

\section{Conclusions}

1. As a result of the research it was found that in both, tapped and non-tapped pines, the average widths of radial increments of the inner zone were greater than in the outer zone created after 1965 when tapping ended.

2. In tapped trees, at the level A the average growths eastwards, i.e. on the vital strip, were characterised by a very small decrease in width (by $12.3 \%$ ) between the inner and outer zones. In non-tapped trees this difference was significant (60.4\%). The average width of rings in the outer zone of the vital strip was at the same time as much as $159 \%$ larger compared to the similar location in non-tapped trees.

3. In the tapped trees on the extension of the tapping areas, at the heights B and C, the average widths of rings in the outer zone were respectively $53.1 \%$ and $50.0 \%$ smaller than in the inner zone. On the extension of vital strips, they were only $37.3 \%$ and $39.2 \%$ smaller, respectively.

4. The width of the radial growth of pine trees after resin tapping has grown dynamically, mainly on vital strips and then on their extensions; on extensions of tapping areas, the growths increased towards the trunk circumference to a small extent, similar to that recorded at the $\mathrm{DBH}$ height in non-tapped trees.

5. Increased growth on vital strips, as well as over them indicates the optimisation of the shape of the trunk, which is a reaction to mechanical damage through strengthening the undamaged part.

The research was financed with a grant awarded by the Ministry of Science and Higher Education for statutory activities.

\section{References}

Barszcz A. 2007. Aktualne problemy i możliwości użytkowania ubocznych surowców drzew leśnych. W: Las to nie tylko drewno. Red. S. Staniszewski. Wyd. Świat, Warszawa, 31-39.

Biotronik 2001. Przyrostomierz SGM, Przyrost WP.

Chen F., Yuan Y.J., Yu S.L., Zhang T.W. 2015. Influence of climate warming and resin collection on the growth of Masson pine (Pinus massoniana) in a subtropical forest, southern China. Trees, 29: 1423-1430.

Frommhold H., Temmen H. 1995. Absatzchancen gehartzter Kiefern. AFZ/Der Wald, 45 (25): 1365-1367.

Génova M., Caminero L., Dochao J. 2014. Resin tapping in Pinus pinaster: effects on growth and response function to climate. Eur. J. For. Res., 133: 323-333. 
Grochowski W. 1990. Uboczna produkcja leśna. PWN, Warszawa.

Instrukcja żywicowania. 1987. NZLP, Warszawa.

Jelonek T. 2013. Biomechaniczna stabilność drzew a wybrane właściwości fizyczne, mechaniczne i strukturalne ksylemu sosny zwyczajnej (Pinus sylvestris L.) wyrosłej w warunkach gruntów porolnych i leśnych. Rozprawy Naukowe, 455. Wydawnictwo UP w Poznaniu.

Jezierski F. 1930. Zagadnienie wpływu żywicowania sosny zwyczajnej na jej przyrost. Sylwan, 48(2): 78-110.

Kätzel R., Löffler S., Naumann A. 1995. Biochemische Untersuchungen zum Gesundheitszustand gaharzter Kiefern, Eberswalde. AFZ/Der Wald, 50(25): 1360-1364.

Magnuszewski M., Tomusiak R. 2013. Wpływ żywicowania na przyrost radialny sosny zwyczajnej (Pinus sylvestris L.) na przykładzie drzewostanu w Nadleśnictwie Lidzbark. Leśne Prace Badawcze, 73(3): 273-280.

Papadopoulos A.M. 2013. Resin tapping history of an aleppo pine forest in Central Greece. Open For. Sci. J., 6: 50-53.

van der Maaten E., Mehl A., Wilmking M., van der Maaten-Theunissen M. 2017. Tapping the tree-ring archive for studying effects of resin extraction on the growth and climate sensitivity of Scots pine. For. Ecosyst., 4(7). DOI:10.1186/s40663-017-0096-9

Williams R., Nauman C., Zhu J. 2017. The effects of resin tapping on the radial growth of Masson pine trees in South China. A Case Study. Agri. Res. \& Tech. Open Access J. 8 (2). DOI: 10.19080/ARTOAJ.2017.08.555732

\section{KSZTAŁTOWANIE SIĘ SZEROKOŚCI StOJÓW ROCZNYCH SOSNY ZWYCZAJNEJ W NASTĘPSTWIE ŻYWICOWANIA}

\section{STRESZCZENIE}

Materiał do badań pobrano z drzewostanu sosnowego w Nadleśnictwie Świerklaniec w wieku 164 lat. Omawiany drzewostan żywicowano w latach 1964-1965 w obiegu 2-letnim. Na sosnach jednospałowych spały zakładane były od strony zachodniej. Spośród ściętych drzew wybrano 3 sztuki ze spałami. Ze ściętych drzew pobrano następnie po 3 krążki drewna z następujących wysokości: krążki oznaczone symbolem A - $1 \mathrm{~m}$ od czoła dolnego, w obrębie spały wykonanej 47 lat wcześniej (w 2. roku żywicowania) oraz B - w odległości 2,60 m i C w odległości 3,80 m od czoła dolnego. Krążki B i C znajdowały się powyżej górnej krawędzi spały. Do celów porównawczych z 3 drzew stojących, nieżywicowanych, pobrano świdrem Presslera wywierty z wysokości 1,30 m od podstawy drzew, z kierunków zachodniego i wschodniego. Zebrany materiał analizowano, wykonując pomiar szerokości przyrostów radialnych pnia drzew żywicowanych i nieżywicowanych od strony zachodniej i wschodniej z uwzględnieniem dwóch stref: 1 - wewnętrznej, od rdzenia do 1965 roku, tj. do drugiego roku żywicowania włącznie, oraz 2 - zewnętrznej, od 1966 do 2012 roku.

Dla wszystkich drzew, żywicowanych i nieżywicowanych, średnie szerokości przyrostów rocznych w strefach wewnętrznych były większe niż w strefach zewnętrznych. U drzew żywicowanych na wysokości A, w kierunku wschodnim, tj. na pasie życiowym, średnie 
szerokości przyrostów były w strefie zewnętrznej tylko o 12,3\% mniejsze niż w wewnętrznej. Analogicznie różnica ta u drzew nieżywicowanych wynosiła aż 60,4\%. U drzew żywicowanych na przedłużeniu spał (od strony zachodniej), na wysokości B i C średnie szerokości słojów w strefie zewnętrznej były odpowiednio o 53,1\% oraz o 50,0\% mniejsze niż w wewnętrznej. Od strony wschodniej, na przedłużeniu pasów życiowych, na wysokości B, były one tylko o $37,3 \%$, a na wysokości C o 39,2\% mniejsze niż w strefie wewnętrznej. Badanie to potwierdziło teorię optymalizacji kształtu drzewa poprzez zwiększenie przyrostu w części obwodu, która nie została bezpośrednio dotknięta uszkodzeniem mechanicznym: w tym przypadku uszkodzenie było spowodowane spałą żywiczarską.

\section{SŁOWA KLUCZOWE}

spała żywiczarska • wady drewna • deformacja pnia • uszkodzenia mechaniczne 